\title{
Rising trend in paediatric eosinophilic esophagitis incidence in Spain: results of a prospective study 2014-16
}

\author{
Enrique La Orden Izquierdo ${ }^{1}$, IGNACIO MAHILLO² ${ }^{2}$, Sonia Fernández Fernández ${ }^{3}$, Josefa \\ Barrio Torres ${ }^{4}$, Enriqueta Román Riechmann ${ }^{5}$, and Carolina Gutiérrez Junquera ${ }^{5}$ \\ ${ }^{1}$ Hospital Universitario Infanta Elena \\ ${ }^{2}$ IIS-FUNDACION JIMENEZ DIAZ \\ ${ }^{3}$ Severo Ochoa University Hospital \\ ${ }^{4}$ Hospital Universitario de Fuenlabrada \\ ${ }^{5}$ Hospital Universitario Clinica Puerta de Hierro
}

November 10, 2020

\begin{abstract}
Objetives: The rate of eosinophilic esophagitis (EoE) diagnosis is increasing. This study aims to determine the incidence of EoE in the paediatric population residing in the southwestern Madrid and to analyse whether absolute monthly pollen counts, modified or not by the principal atmospheric pollutants, are associated with it. Methods: A prospective observational study was designed to calculate the incidence of EoE in children aged under 15 years who were diagnosed between September 2014 and August 2016 in twelve area hospitals. We collected clinical data, date of endoscopic diagnosis and the number of first-time endoscopies performed. Relative risk estimation was performed to assess the association between the incidence of diagnosis and monthly pollen counts and levels of atmospheric pollutants. Results: One hundred forty-eight patients were included. The most frequent symptoms were abdominal pain $42.57 \%$, dysphagia $42.57 \%$ and impaction $39-86 \%$. The average overall monthly incidence was 1.27 (0.41-2.67) cases/100,000 children and the annual average was 15.2 . The overall analysis of the relationship between incidence and absolute monthly counts and air pollutants, corrected for the number of first-time endoscopies performed, revealed no statistically significant association. There was a higher frequency of diagnosis during the pollination period of Cupressaceae and during February and November (relative risk 1.67; $\mathrm{p}<0.01$ ). Conclusions: This study confirms the high incidence of eosinophilic esophagitis and also suggest a period of higher incidence of diagnosis in the months of February and November as well as in the period of high pollination of Cupressaceae.
\end{abstract}

\section{Hosted file}

Manuscript (1).pdf available at https://authorea.com/users/374650/articles/492097rising-trend-in-paediatric-eosinophilic-esophagitis-incidence-in-spain-results-of-aprospective-study-2014-16

\section{Hosted file}

Table 1.pdf available at https://authorea.com/users/374650/articles/492097-rising-trend-inpaediatric-eosinophilic-esophagitis-incidence-in-spain-results-of-a-prospective-study2014-16

\section{Hosted file}

Table 2.pdf available at https://authorea.com/users/374650/articles/492097-rising-trend-inpaediatric-eosinophilic-esophagitis-incidence-in-spain-results-of-a-prospective-study2014-16 


\section{Hosted file}

Table 3.pdf available at https://authorea.com/users/374650/articles/492097-rising-trend-inpaediatric-eosinophilic-esophagitis-incidence-in-spain-results-of-a-prospective-study2014-16

\section{Hosted file}

Figure 1.pdf available at https://authorea.com/users/374650/articles/492097-rising-trend-inpaediatric-eosinophilic-esophagitis-incidence-in-spain-results-of-a-prospective-study2014-16 